\title{
Aktualność wschodnich koncepcji Jerzego Giedroycia
}

$\mathrm{M}$ iesięcznik „Kultura”, wydawany w latach 1947-2000 przez Instytut Literacki w Paryżu, jest rozpoznawany jako dzieło życia Jerzego Giedroycia, założyciela pisma i wydawnictwa, jedynego redaktora przez ponad 50 lat, twórcę ośrodka myśli politycznej. Usytuowanie redakcji czasopisma z dala od sporów emigracyjnych paradoksalnie sprzyjało rozwojowi Instytutu, a „Kultura” - pomimo antagonizmów z „niezłomnym” Londynem - zdobywała czytelników i uznanie za próby nowego spojrzenia na miejsce Polski w powojennej Europie. Optykę Maisons-Laffitte wytyczały dwa stałe punkty: uznanie granicy wschodniej i zachodniej oraz rewizja narodowościowej polityki II RP - w taktyce krajowej i zadaniach dla emigracji. Oparty na tych założeniach program wschodni „Kultury” zakładał konieczność przełamania stereotypów oraz uprzedzeń historycznych w stosunkach Polski, Ukrainy, Litwy, Białorusi (ULB) w celu przygotowania podłoża dla strategicznego partnerstwa w tym obszarze. Twórca koncepcji - Juliusz Mieroszewski przekonywał do wizji niepodległej Polski sąsiadującej z suwerennymi państwami obszaru ULB po rozpadzie Związku Socjalistycznych Republik Radzieckich. Uzasadniał moralną i polityczną wymowę deklaracji wyrzeczenia się Wilna i Lwowa. Wskazywał na analogię losów wypędzonych z Kresów Wschodnich do europejskich dramatów utraty małych ojczyzn. Pisał scenariusze pojednania z Ukraińcami, Litwinami, Niemcami, z dużą wrażliwością odnosząc się do zadawnionych kompleksów oraz świeżych lęków podsycanych przez propagandę Polskiej Rzeczypospolitej Ludowej.

Wielką satysfakcją Redaktora było to, iż mógł w ostatniej dekadzie swego życia obserwować, jak koncepcje wypracowane przez publicystów z kręgu „Kultury” stają się wytycznymi polityki zagranicznej niezależnej Polski. Wśród nich największe znaczenie osiągnęła myśl o dobrosąsiedzkich stosunkach z ULB, czyli Ukrainą, Litwą i Białorusią, mająca swoją genezę jeszcze w działalności politycznej i redaktorskiej Giedroycia przed 1939 rokiem.

W słynnym Przesłaniu, o którym Krzysztof Pomian trafnie powiedział, że stanowi „jakby rozmowę z Polską o niej samej”", Jerzy Giedroyc napisał, że „szansą może być

\footnotetext{
1 Por. Linia podziału. Z Krzysztofem Pomianem rozmawia Andrzej Garlicki, „Polityka” 1994, nr 49 (1961), s. 3.
} 
nasza polityka wschodnia. Nie wpadając w megalomanię narodową musimy prowadzić samodzielną politykę, a nie być klientem Stanów Zjednoczonych czy jakiegokolwiek innego mocarstwa. Naszym głównym celem powinno być znormalizowanie stosunków polsko-rosyjskich i polsko-niemieckich przy jednoczesnym bronieniu niepodległości Ukrainy, Białorusi i państw bałtyckich, i przy ścisłej współpracy z nimi. Powinniśmy sobie uświadomić, że im mocniejsza będzie nasza pozycja na wschodzie, tym bardziej będziemy się liczyli w Europie Zachodniej”’2.

W zakończeniu Autobiografii na cztery ręce oraz Notatkach ukazujących się w „Kulturze" w latach 90. XX wieku postulował poszanowanie praw mniejszości oraz religii prawosławnej jako nieodzowny warunek nawiązania przyjacielskich kontaktów w obszarze ULB oraz z Rosją. Komentując dla jednego z najlepszych polskich tygodników opiniotwórczych czytelnikowską edycję korespondencji Juliusza Mieroszewskiego, jeszcze raz podkreślił, że najważniejsze i nadal aktualne są jego poglądy w kwestii ULB, zwłaszcza wokół konieczności ułożenia równych stosunków ze wschodnimi sąsiadami, oraz przekonanie, że obowiązkiem elit kulturalnych i politycznych jest poznanie historii oraz tradycji Rosji, która pozostaje naszym sąsiadem i nadal jest potężnym mocarstwem, w tym zwalczanie pogardy wobec Rosjan ${ }^{3}$.

Uwagę zwraca również fakt, że autorzy większości wspomnień i druków okolicznościowych opublikowanych po śmierci Jerzego Giedroycia akcentują jego osobiste zaangażowanie $\mathrm{w}$ problematykę rozsupłania trudnego węzła polsko-wschodnich uprzedzeń, np.: Bohdan Osadczuk, Czesław Miłosz, Leszek Kołakowski, Jan Nowak-Jeziorański, Jacek Bocheński, Andrzej Romanowski (który użył nawet określenia „szlak Giedroycia", czyli solidarności między narodami Europy Środkowo-Wschodniej)4 ${ }^{4}$ Jerzy Kłoczowski, Krzysztof Pomian.

Jerzy Giedroyc wielokrotnie indagowany o genezęi u mocowanie programu wschodniego „Kultury” przyznał, że odejście od żądań terytorialnych najpierw przysporzyło czytelników z Ukrainy i Europy Wschodniej, a później utrwaliło pozycję pisma jako godnego zaufania rzecznika porozumienia. Sztywne stanowisko rządu londyńskiego w sprawie granicy ryskiej nie było uzasadnione względami geograficznymi i etnograficznymi. Dlatego publicyści „Kultury” skierowali wszystkie wysiłki na wzbudzenie świadomości oddzielającej wielką politykę od osobistych, sentymentalnych więzi z Kresami. Giedroyc stawiał na niezależną Ukrainę spełniającą rolę bufora pomiędzy Polską

J. Giedroyc, Autobiografia na cztery ręce, oprac. K. Pomian, Warszawa 1994, s. 228.

3 Zacytujmy: „Zwłaszcza nie stracił na aktualności pogląd J. Mieroszewskiego o konieczności ułożenia równych stosunków ze wschodnimi sąsiadami. Trzeba to stale powtarzać, gdyż politykom brakuje tej świadomości. Wystarczy przypomnieć traktowanie przez nasze władze cywilne i kościelne mniejszości litewskiej i prawosławnej. Uważa się niekiedy, że skoro są mało liczne, nie warto przykładać do tego wagi. Tymczasem nasi sąsiedzi wyciągają wnioski o stosunku do nich z polityki wschodniej prowadzonej wobec mniejszości”. Por. J. Giedroyc, Polak zachodni, „Polityka” 1999, $\mathrm{nr} 47$ (2220), s. 66. W tym samym artykule J. Giedroyc w ostrych słowach polemizuje z zasadami polityki Senatu i Stowarzyszenia Wspólnota Polska wobec Litwy.

4 Por. Xiążę Redaktorów. Wspominają go „Gazeta Wyborcza”, 16-17.09.2000, nr 217.3518, s. 10-12. 
i Rosją. Mówił: „Z wytycznych, które nam przyświecały, najważniejsze było odpowiedzenie sobie na pytanie, jaką rolę winna Polska odgrywać we wschodniej Europie. Nasze założenia ideowe wiązały się w pewnym sensie z koncepcjami Józefa Piłsudskiego, ma się rozumieć zmodyfikowanymi. Doszliśmy więc do przekonania, że rola Polski na Wschodzie jest nadal ogromna, ale inna niż by to wynikało z koncepcji jagiellońskich. Dzisiaj są one kompletnie nierealne na skutek nacjonalizmów narodów sąsiadujących z Polską od wschodu. Powtarzanie tego spotkałoby się z podobną reakcją, z jaką spotkał się federalizm Piłsudskiego. Byłoby to uznane za nową formę imperializmu polskiego. Nie można było powielać dawnych koncepcji federacyjnych. Wszystkie te ideały były, i są do dziś, przyjmowane z niesłychaną nieufnością przez narody ościenne. Aby naszą politykę oprzeć na nowych podstawach i nie być posądzonym o imperializm, trzeba zdecydować się na ofiary, nie ma wielkiej, długofalowej polityki bez ofiar. Dlatego też nasz zespół od razu się zdecydował, jeszcze w 1949 roku, że Wilno i Lwów są dla Polski stracone. Jeżeli chcemy znormalizować nasze stosunki z Litwą i z Ukrainą, to z tych miast musimy zrezygnować. Musimy zrezygnować $\mathrm{z}$ rewindykacji tych ziem nawet po zmianie sytuacji. Tym się różniliśmy od reszty emigracji, która sprawę utraconych ziem chce odłożyć do czasu odzyskania niepodległości przez Polskę"5.

Jerzy Giedroyc i współpracujący z nim publicyści wykorzystywali każdą sposobność, by przekonać czytelników „Kultury” oraz „Zeszytów Historycznych”, że - według słów Redaktora - „przyszłość Polski jest bez wątpienia uzależniona w olbrzymiej mierze od przekreślenia przez dzisiejsze i nadchodzące pokolenia antagonizmów dzielących nas od narodów mieszkających na wschód od Bugu. Ważności tej sprawy nie można przecenić. Nasza rola na wschodzie nie zmalała, a wręcz przeciwnie, stała się większa [...] Polska z uwagi na wartości swojej kultury, jak i dziedzictwo myśli demokratycznej może i powinna stać się wzorem i zwornikiem dla narodów i państw tej części Europy”.

Na zainteresowanie J. Giedroycia tematyką wschodnią bez wątpienia wpłynęły następujące fakty: miejsce urodzenia (Mińsk Litewski), przekazy o świetności i legendzie rodziny (ród książęcy odnotowany w XV- i XVI-wiecznych kronikach)" , studia nad historią Ukrainy pod kierunkiem prof. Mirona Korduby na Uniwersytecie Warszawskim, znajomość z Dymitrem Fiłosofowem, Piotrem Kontnym, Jerzym Stempowskim, Stanisławem Vincenzem, krytyczny stosunek wobec polityki narodowościowej II Rzeczypospolitej, wyrażany m.in. na łamach powołanego w 1931 roku „Buntu Młodych” (pod zmienioną nazwą „Polityka” od 1937 roku).

Jerzy Giedroyc wcześniej niż przedstawiciele pozostałych środowisk dostrzegł możliwość wykorzystywania aspiracji niepodległościowych Ukraińców, Litwinów, Białorusinów, Rosjan. Postawił na wspólny front antykomunistyczny. Posiadając ograniczone

Droga na Wschód. Z Jerzym Giedroyciem rozmawia M. Zieliński, „Więź” 1989, nr 10 (397), s. 42-50. Ibidem.

7 Por. E. Berberyusz, Książę z Maisons-Laffitte, Gdańsk 1994; M. Kosman, Jerzy Giedroyc - człowiek instytucja, [w:] idem, Z rozważań nad kultura polityczna w Polsce, cz. 2, Poznań 2001, s. 101-115. 
- do wydawnictwa - możliwości uprawiania polityki, budowania sojuszy itp., rozwinął szeroką akcję publicystyczną, stawiając przed autorami „Kultury” zadanie przekonania rodaków do głoszonych poglądów. Redaktor nawiązywał do koncepcji prometeizmu. Miał pewność, że dla imperializmu rosyjskiego najgroźniejsze jest rozbudzenie świadomości narodowej państw zniewolonych, a w konsekwencji emancypacja republik związkowych. Niepodległość Polski wiązał ze stopniowym osłabieniem Rosji.

W roku 1952 na łamach „Kultury” ukazał się list ks. Józefa Majewskiego (K. nr 11/61). Wywołał on burzliwą dyskusję korespondencyjną i sprowokował Redakcję do jasnego sformułowania stanowiska w sprawie Wilna i Lwowa. Myśl tam zawarta, tzn. uznanie bezpowrotnej utraty miast symbolicznych dla Polaków oraz zgoda na przebieg wschodniej granicy, była wyrazem niespotykanej odwagi. Kwestionowała wszystkie dogmaty, atakowała nawyki myślowe emigrantów niepodległościowych, uderzała w sam rdzeń doktryny komunistycznej oraz podważała sens polityczno-wojskowych sojuszy Zachodus.

Jerzy Giedroyc uważał, że koniecznym dopełnieniem walki Polaków z ideologią komunistyczną w kraju jest jasno sformułowany program polityki wschodniej, który powinien obejmować również nawiązanie kontaktów z rosyjską opozycją demokratyczną. Termin „europeizacja Rosji” oznaczający w publicystyce Mieroszewskiego stopniowe przekształcenie świadomości ujarzmionego narodu oraz przywracanie Rosjanom godności i poczucia praw człowieka opisywał również w kategoriach historyczno-politologicznych jako odwrócenie perspektywy w ocenie rzeczywistego imperializmu państw-sojuszników zwycięskich w II wojnie światowej. „Kultura” stosunkowo wcześnie podjęła próbę dotarcia do ZSRR za pośrednictwem sekretarza „Nowego Mira” Baranowa. W Instytucie wydano książki Andrzeja Siniawskiego i Julija Daniela. W Zurychu odbyło się spotkanie Gierdoycia i Czapskiego z wydalonym przez władze radzieckie Aleksandrem Sołżenicynem (w 1974 roku w Bibliotece „Kultury” ukazał się Archipelag Gułag). Wraz z Gustawem Herlingiem-Grudzińskim i Józefem Czapskim przystąpili do zespołu rosyjskiego pisma „Kontynent” założonego przez Władimira Maksimowa.

Do ważnych przejawów realizacji dialogu ze wschodnimi sąsiadami należy zaliczyć opublikowanie antologii Rozstrilane widrodżenije, książki Stanisława Kota Jerzy Niemirycz. W 300-lecie ugody hadziackiej oraz opracowania Iwana Koszeliwca Ukraina 1956-1968 (seria „Dokumenty”). W 1977 roku dzięki staraniom Jerzego Giedroycia redaktorzy pism emigracyjnych „Kontinent”, „Svedectivi”, „Irodalmi Ujsag”, „Kultura” oraz dwudziestu ośmiu działaczy Ruchu Demokratycznego w ZSRR podpisało deklarację na temat niepodległości Ukrainy i innych narodów wschodnioeuropejskich? . Jak już wspomniałam, przełomową rolę w procesie kształtowania świadomości politycznej środowi-

8 Por. A. Michnik, Jak być Polakiem na paryskim bruku, [w:] Jerzy Giedroyc. Redaktor, Polityk, Człowiek, red. K. Pomian, Lublin 2001, s. 135-150.

9 Dokument wypunktowuje przede wszystkim jednakowe doświadczenia narodów walczących z „sowieckim kolonializmem” oraz prawo Ukraińców do niezależnego bytu państwowego. Sygnatariuszami deklaracji byli: A. Amarlik, W. Bukowski, Z. Byrski, J. Czapski, J. Giedroyc, N. Gorbaniewska, G. Herling-Grudziński, J. Łobodowski, W. Maksimow, T. Meray, D. Morawski, 
ska Maisons-Laffitte odegrała publikacja listu ks. Józefa Majewskiego, a właściwie odzew czytelników z całego świata. Przedsmakiem dyskusji śmiało można nazwać długą, aż 53-stronicową wypowiedź Józefa Łobodowskiego Przeciw upiorom przeszłości.

W manifeście tym Łobodowski skomentował długą i zasadniczą listę „sąsiedzkich kompleksów i urazów" skutecznie uniemożliwiającą gesty pojednania. Przeciwstawił ukraińskiemu, zadawnionemu poczuciu krzywdy polską ignorancję, megalomanię oraz mocarstwową frazeologię. Łobodowski apelował: „Czas byłby najwyższy, aby Polacy zrozumieli, że Ukraińcy są odrębnym narodem o takim samym prawie do samoistności, jakie przysługuje każdemu innemu narodowi. Że szereg cech ujemnych, które nas rażą, albo dają się nam dotkliwie we znaki powstał na skutek tragicznej historii i nienormalnego rozwoju kultury narodowej, stale krępowanej przez nieprzyjazne okoliczności. Że wreszcie zły to patriota, który sąsiadowi zza miedzy odmawia takich samych uczuć patriotycznych [...] A przede wszystkim trzeba skończyć z fałszywym jaśniepaństwem [...] Ukraińcom zaś wyszłoby na dobre, gdyby przeprowadzili chociaż częściową rewizję swych poglądów nad dawną Rzeczpospolitą, a na międzywojenne dwudziestolecie spojrzeli także od strony polskiej”10.

List ks. Józefa Majewskiego współgrał z twierdzeniami Łobodowskiego, przekładając pełen niuansów znaczeniowych tekst deklaracji na możliwie najprostszy postulat: przystać na litewskie Wilno oraz ukraiński Lwów w zamian za Wrocław, Gdańsk, Szczecin, zdobyć zaufanie sąsiadów dla projektu federacji Europy Środkowo-Wschodniej. Pod naporem okoliczności ukazała się Nota Redakcji. Nieporozumienie czy tani patriotyzm (K. $1953 \mathrm{nr}$ 1/63). Jej znaczenie polega na zaakcentowaniu związku federacyjnego Polski z obszarem ULB oraz obowiązku podjęcia starań przez emigracje narodowe na rzecz przyszłych, dobrosąsiedzkich stosunków.

Pierwszy nurt początkowo najpełniej rozwijał się w publicystyce Juliusza Mieroszewskiego - „Londyńczyka”. Mieroszewski przypominał o konieczności wyzbycia się mentalności „przedmurza” Zachodu lub Wschodu (zależnie od koniunktury) oraz aktualizacji myśli politycznej stosownie do zmian geopolitycznych w Europie ${ }^{11}$.

Szczytowym osiągnięciem publicysty było sformułowanie najważniejszych przesłanek polskiej polityki wschodniej w cyklu studiów na „Ostpolitik" i „Westpolitik”, m.in. w kontekście amerykańskim ${ }^{12}$. Biorąc pod uwagę sytuację międzynarodową, Mieroszewski punktował następujące zasady obowiązujące w programie wschodnim „Kultury”: słaba pozycja Rosji w Europie Wschodniej, de facto ciągła okupacja wojskowa w państwach bloku, wzrost świadomości narodowej, proporcjonalnie do natę-

W. Niekrasow, A. Smolar, P. Tigrid. Por. Deklaracja w sprawie ukraińskiej, „Kultura” 1977, nr 5/356, s. 66-67.

10 J. Łobodowski, Przeciw upiorom przeszłości, „Kultura” 1952, nr 2/52-3/53, s. 48.

11 Por. Londyńczyk, Kronika angielska, „Kultura” 1970, nr 9/276; J. Mieroszewski, O banałach i cudach w polityce, „Kultura” 1972, nr 4/295.

12 Por. idem, Amerykańska „Ostpolitik” i wnioski, „Kultura” 1972, nr 7/298-8/299; Polska „Ostpolitik”, „Kultura” 1973, nr 6/309; Polska „Westpolitik”, „Kultura” 1973, nr 9/312; Rosyjski „kompleks polski” i obszar ULB, „Kultura” 1974, nr 9/324. 
żenia akcji rusyfikacyjnych, ścisłe współdziałanie z „prawdziwymi”: Ukrainą, Litwą i Białorusią. Mieroszewski przywiązywał wagę do zrozumienia przez swoich czytelników związków pomiędzy wyzwoleniem obszaru ULB a pozycją Polski wobec mocarstwowej Rosji. Powtarzając: „Pierwszym punktem polskiej polityki wschodniej winno być uznanie prawa do samostanowienia i niezależnego bytu państwowego wszystkich narodów ciemiężonych przez Sowiety [...] ponieważ zgoda i jednolity front narodów ujarzmionych stanowi podstawowy warunek likwidacji [...] imperializmu rosyjskiego - winniśmy [...] zapewnić Ukraińców i Litwinów, że nie zgłaszamy roszczeń rewindykacyjnych do Wilna i Lwowa" ${ }^{13}$, liczył na wzajemne odpuszczenie win historycznych oraz porozumienie w obliczu istniejącego zagrożenia ze strony Rosji. „Londyńczyk” podjął się akcji edukacyjnej na elementarnym poziomie, np. tłumacząc problemy społeczno-polityczne w relacjach narodów Europy Wschodniej zaszłościami historycznymi i polityką imperialną Rosji.

W roku 1974 Juliusz Mieroszewski użył po raz pierwszy skrótu ULB, pisząc m.in., że obszar ten „determinował formę stosunków polsko-rosyjskich skazując nas albo na imperializm, albo na satelictwo" ${ }^{14}$. Uporczywe przypominanie głównych założeń programu wschodniego „Kultury” odniosło taki skutek, że świadomość utraty czy ofiary Wilna i Lwowa niepostrzeżenie czyniła coraz większe wyłomy w jednolitej postawie emigracji „niezłomnej”. W „Kulturze” dominowało przekonanie, że szansą dla ziem położonych między Rosją i Niemcami jest „niepodległość zrzeszona”, a więc federacja, związek państw neutralnych oraz zmiana nastawienia w stosunku do Rosji. Od najwcześniejszych lat funkcjonowania pisma zdawano sobie sprawę z kluczowego znaczenia Ukrainy, o czym świadczyło np. uruchomienie „Kroniki”, specjalnej rubryki dedykowanej emigrantom z Europy Wschodniej ${ }^{15}$. Kroniki odegrały olbrzymią rolę jako źródło informacji i symboliczna obecność narodów zniewolonych w dyskursie publicznym.

Zasługą Mieroszewskiego było przełamywanie tabu - wyraziste wyartykułowane tezy, że Polska może być bezpieczna i suwerenna bez Kresów oraz że walka o granicę wschodnią sprzed 1939 roku z żądaniem nienaruszalności obecnej granicy polsko-niemieckiej kształtuje wizerunek Polski rewizjonistycznej z aspiracjami mocarstwowymi.

13 Idem, Polska „Ostpolitik”, „Kultura” 1973, nr 6/309, s. 76.

14 Idem, Rosyjski „kompleks polski” i obszar ULB, „Kultura” 1974, nr 9/324, s. 9.

15 „Kronikę ukraińską” na przestrzeni lat 1952-1999 redagowali: Bohdan Osadczuk, Borys Lewičkyj, Andrzej Vincenz, Benedykt Heydenkorn, Dominik Morawski, Władysław Żeleński, Józef Darski. Jej uzupełnienie stanowiły przeglądy czasopism i wydawnictw ukraińskich. Animatorem „Kroniki litewskiej” w latach 1974-1990 był E. Żagiell (ps. Edmunda Jakubowskiego), zastąpiony w 1992 roku przez J. Darskiego. Mniej regularnie ukazywała się „Kronika białoruska” (pierwszy odcinek w 1955 roku przygotował A. Vincenz). W latach 1977-1982 odpowiedzialnym za zawartość rubryki był Włodzimierz Brylewski, następnie od 1986 roku do 1992 roku - J. Darski. Rolę kronik jako odmiennych form publicystycznych służących realizacji koncepcji J. Mieroszewskiego przedstawiam szerzej w artykule Kroniki emigracyjne paryskiej „Kultury”. Rekonesans badawczy, „Annales Universitatis Mariae Curie-Skłodowska, sectio K. Politologia", Lublin 2002, s. 87-99. 
Publicysta dowodził, że uznając wszystkie granice za ostateczne, Polska korzystnie łączy politykę wschodnią i zachodnią. Wiążąc koncepcję ULB z kwestią rosyjską, widział potrzebę odkłamywania historii konfliktów polsko-rosyjskich. Głosując za trwałą suwerennością obszaru ULB, Mieroszewski miał nadzieję na zakończenie rywalizacji polsko-rosyjskiej o tereny oddziaływania politycznego.

Spadkobiercą idei Mieroszewskiego stał się Bohdan Osadczuk, przez lata autor kronik i komentarzy politycznych, szczególnie aktywny w dekadzie wolności dla Europy Środkowo-Wschodniej. W latach 90. XX wieku Osadczuk na podstawie własnego doświadczenia oraz kontaktów z wieloma przedstawicielami ukraińskiej, litewskiej, białoruskiej i rosyjskiej inteligencji potwierdzał znaczenie projektów „Kultury” dla rozwoju ośrodków opozycji oraz niezależnej myśli powiązanej z emigracją i co ważniejsze - czerpiącej z dorobku pisma.

Strategia dobrosąsiedzkich stosunków z Rosją i równocześnie z obszarem ULB nie znajduje precedensu w dziejach polskiej myśli politycznej. Formuła Jerzego Giedroycia, udoskonalona piórem m.in. Mieroszewskiego, stanowiła wyraźny drogowskaz dla aktywności zagranicznej niepodległej Polski; w zmienionych warunkach po 1989 roku nie uległa przedawnieniu, a co ważniejsze - zyskała aprobatę w zróżnicowanym środowisku politycznym ${ }^{16}$. Nadal wydaje się jedyną doktryną polityki wschodniej, którą dysponujemy, opartą na odrzuceniu uprzedzeń nacjonalistycznych oraz nawiązaniu trudnej przyjaźni z narodami ukraińskim, litewskim, białoruskim. Jerzy Pomianowski, redaktor ważnego dla kontynuacji myśli Giedroycia pisma „Nowaja Polsza”, streścił dyrektywę powstałą w kręgu „Kultury” następująco: „Partnerstwo z Rosją tak, ale nie kosztem wspólnych sąsiadów, kto chce uniknąć konfliktów, musi uznać ich niepodległość" ${ }^{17}$. Nowoczesne odczytanie dziedzictwa historycznego Rzeczypospolitej przez Jerzego Giedroycia polegało zdaniem Jerzego Kłoczowskiego na wypracowaniu i rozwoju dobrych stosunków z sąsiadami w poszanowaniu odrębności kulturowej, co sprzyja stabilizacji Polski w Europie ${ }^{18}$. Te same elementy ponadczasowości koncepcji ULB wydobywali Leszek Kołakowski, Bohdan Osadczuk, Jacek Bocheński, Ryszard Kaczorowski, Czesław Miłosz, Krzysztof Pomian.

W wywiadach udzielonych w ostatnim dziesięcioleciu życia (a zarazem w momencie, gdy „Kultura” była już w oficjalnym, legalnym obiegu) Jerzy Giedroyc bezustannie przypominał o szczególnej roli Polski na Wschodzie. Mówił: „Polska ma możliwość odegrania wielkiej roli na Wschodzie i w środkowej Europie. Tymczasem robi się absolutnie wszystko, aby te możliwości przekreślić i zaprzepaścić. Sprawą dla mnie najważniejszą jest dziś możliwie jak najszybsza normalizacja stosunków z Litwą i krajami bałtyckimi, a następnie nawiązanie bliższych kontaktów z Ukrainą i Litwą" ${ }^{19}$. Z pespek-

16 Por. J. Pomianowski, Wspomnienia o Jerzym Giedroyciu, „Gazeta Wyborcza” 16-17.09.2000, nr 218/3518, s. 17-18.

17 Idem, Prawdziwy król bez ziemi, „Rzeczypospolita”, dodatek „Plus-Minus” 2000, nr 37 (403), s. 2.

18 Ibidem.

19 Dlaczego nie przyjechałem do Polski. Doktorat honoris causa dla Giedroycia, „Gazeta Wyborcza” 1991, nr 262, s. 7. 
tywy lat i na tle innych, znaczących programów podejmowanych w Maisons-Laffitte należy przyznać, że zachował on największą aktualność. Historyczną wartość posiada jedynie spór o polskie Wilno i Lwów, którego próba zracjonalizowania stanowiła podłoże idei Juliusza Mieroszewskiego. Wnikliwie pisał o tym Jerzy Pomianowski, wysoko oceniając strategię tworzenia warunków porozumienia Polski, Ukrainy, Litwy, Białorusi i Rosji w kontekście współczesnych wydarzeń2 ${ }^{20}$. Zacytuję: „Giedroyc zbudował strategię polityczną, która nie miała precedensu w dziejach polskiej myśli. I zdołał przekonać do niej najbystrzejsze umysły w kraju. Giedroyc zostawił drogowskaz dla polskiej polityki zagranicznej, zwłaszcza gdy chodzi o jedyny teren, na którym mamy wciąż jeszcze swobodę manewru, tj. o politykę wschodnią. To on, razem z Juliuszem Mieroszewskim, zostawili formułę, która bynajmniej się nie przedawniła. Tak jest, dobrosąsiedzkie, jak najlepsze stosunki z Rosją, pod jednym wszelako warunkiem - byle nie kosztem naszych wspólnych sąsiadów, zwłaszcza Ukrainy. To Giedroyc, nie kto inny, miał trzeźwą wizję polskiej przyszłości. To on powiedział kiedyś, że więcej katastrof w dziejach spowodował brak wizji niż brak politycznego pragmatyzmu. Była to wizja suwerenności"21. Podobnie Czesław Miłosz wskazywał na przyjęcie koncepcji wschodniej „Kultury” za „podstawową polską rację stanu” po 1989 roku $^{22}$.

Pośrednio o inspirującym charakterze założeń pisma świadczą wypowiedzi kandydatów na urząd prezydenta przed wyborami w listopadzie w 1995 roku zebrane w ramach ankiety „Jaka Polska na XXI wiek?”23. Pewną satysfakcję J. Giedroyc czerpał ze zgodności własnych poglądów z linią polityki wschodniej prezydenta Aleksandra Kwaśniewskiego ${ }^{24}$. Prezydenci Polski po 1989 roku często odnosili się do dziedzictwa „Kultury” w kontekście programu wschodniego, co szczególnie uwidoczniło się podczas tworzenia pomarańczowej rewolucji oraz $\mathrm{w}$ polityce poakcesyjnej, kiedy Polska aspirowała do roli promotora Europy Wschodniej w Unii Europejskiej. Prezydenci PR oraz ministrowie spraw zagranicznych cytowali „Kulturę” na etapie utrwalania ładu politycznego w Europie Wschodniej. W wielu wypowiedziach publicznych zwracano uwagę, że Polska jako pierwsze państwo uznała niepodległość Ukrainy w 1990 roku, ponieważ grunt społeczno-kulturowy przygotował Giedroyc i „Kultura”. Warto pod-

20 Por. J. Pomianowski, op. cit.

21 Ibidem.

22 Dosłownie - „polityka Giedroycia w stosunku do Ukraińców była i jest przez cały czas niesłychanie zwarta i logiczna. To znaczy, pewnik, że niepodległość Ukrainy leży w interesie Polski; że oddzielenie Polski od Rosji przez Ukrainę jest podstawową polską racją stanu. I stąd pochodziła polityka proukraińska, decyzja o wyrzeczeniu się Lwowa itd." Por. M. Kubik, Rozmowa z Czesławem Miłoszem, „Gazeta Uniwersytecka UŚ”, dodatek kulturalny 14.09.2001, nr 3, s. 19.

23 Por. Jaka Polska na XXI wiek?, „Kultura” 1995, nr 10/577, s. 4-111.

24 Na kwestię dziennikarza: „Ocenia się, że część postulatów Kultury w sprawach wschodnich realizuje w swojej polityce prezydent Kwaśniewski”, Jerzy Giedroyc odpowiedział: „W pewnym stopniu [...] Z chwilą jednak, gdy Kwaśniewski został wybrany, stał się w naszym przekonaniu prezydentem Polski legalnie wybranym, z którym należy współpracować. Ja na tę współpracę z Kwaśniewskim poszedłem z pewnym rezultatem, bo on cały szereg naszych poglądów, jeśli idzie o politykę wschodnią, przejął i stara się je realizować". Por. M. Kubik, op. cit., s. 18. 
kreślić, że Giedroyc w autorskim cyklu komentarzy „Notatki Redaktora”, ukazującym się regularnie od 1995 roku na łamach miesięcznika, krytycznie recenzował realizację polityki wschodniej, zwłaszcza wobec mniejszości narodowych i sporów historycznych. Ze zniecierpliwieniem powtarzał argumenty obecne w „Kulturze” przez blisko pół wieku o konieczności pozostawienia przeszłości do oceny historykom, odpolitycznienia dyskursów historycznych, racjonalizacji stereotypów. W „Kulturze” zamieszczono wiele przekładów literackich, tekstów artystycznych, wspomnień związanych z obszarem ULB, co zdaniem Giedroycia dawało szansę na zrozumienie historii i współczesnych aspiracji.

W roku 2020 minie dwadzieścia lat od śmierci Giedroycia i zamknięcia „Kultury”. Trudno podjąć wyzwanie odpowiedzi na pytanie, co Giedroyc miałby do powiedzenia współcześnie w sprawie polityki wschodniej, bardziej niż kiedykolwiek determinowanej neoimperializmem Rosji. Osłabiona Ukraina, niebędąca członkiem Unii Europejskiej, po aneksji Krymu, podzielona wojną o Donbas staje się tematem dyskusji politycznych wyrażających raczej bezradność wobec faktów, zwłaszcza że w świecie narastają radykalizmy nacjonalistyczne, egoizmy państwowe, a Unia Europejska podlega wewnętrznym rozdźwiękom o zakres działań wspólnotowych.

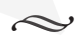

Streszczenie: Jerzy Giedroyc wydawał miesięcznik „Kultura” w latach 1947-2000 w Maisons Laffitte pod Paryżem. Stopniowo „Kultura” stawała się specyficznym ośrodkiem politycznym opartym na publicystyce takich autorów, jak: Juliusz Mieroszewski, Bohdan Osadczuk, Leopold Unger. Mieroszewski był twórcą tzw. koncepcji wschodniej, zakładającej dobrosąsiedzkie stosunki suwerennej Polski z niepodległymi państwami: Ukrainą, Litwą, Białorusią, które wyłonią się wskutek rozpadu ZSRR. Koncepcja ta zrodziła się już w latach 50. XX wieku, a termin ULB został użyty po raz pierwszy w 1973 roku. Oddziaływanie przez publicystykę polegało na przekonaniu opinii publicznej do racjonalizacji sporów historycznych i uznania aspiracji niepodległościowych narodów tworzących w przeszłości Rzeczpospolitą. Po przemianach geopolitycznych i ustrojowych w Europie u schyłku XX wieku uznano, że koncepcja wschodnia "Kultury" ma wymiar aktualny i może stanowić podstawę działań politycznych. Polska jako lider tych zmian przejmowała funkcję orędownika Ukrainy w Unii Europejskiej. Splot okoliczności wewnętrznych (walka polityczna w Ukrainie) i zewnętrznych (przemiany w UE, zmiana priorytetów) spowodował, że Ukraina nie została członkiem UE, mimo zweryfikowanego potencjału społecznego. Koncepcja wschodnia „Kultury” stanowiła jednak mocną przesłankę za uznaniem niepodległości Ukrainy i wsparciem podczas pomarańczowej rewolucji. Dwutorowe działania Giedroycia w sferze kształtowania poglądów politycznych i zmiany stereotypów spowodowały, że bardzo dobrze funkcjonuje współpraca naukowa, kulturalna i społeczna. Rozwija się współpraca w regionach pogranicznych. Fundacje i organizacje pozarządowe prowadzą wspólne inicjatywy na rzecz społeczeństwa obywatelskiego.

Słowa kluczowe: koncepcja ULB, partnerstwo, suwerenność, instrumentalizacja historii 


\section{The Timeliness of Jerzy Giedroyc's Eastern Concepts}

Abstract: Jerzy Giedroyc published monthly magazine "Kultura" from 1947 to 2000 by the Literary Institute in Maisons Laffitte near Paris. Gradually, "Kultura" become a particular political center based on journalistic writing of authors such as: Juliusz Mieroszewski, Bohdan Osadczuk, Leopold Unger. Juliusz Mieroszewski was the creator of the so-called "eastern concept", postulating good neighbourly relations of sovereign Poland with independent states of Ukraine, Lithuania and Belarus, which will emerge as a result of the collapse of the USSR. The concept was born in the 1950s, and the term ULB was used for the first time in 1973. The influence through journalism consisted in convincing the public opinion to rationalize historical disputes and recognize the aspirations for independence of nations that in the past formed the Republic of Poland. After the geopolitical and political changes in Europe at the end of the XX century, it was recognized that "the eastern concept" of "Kultura" has a current dimension and can form the basis for political actions. Poland, as the leader of these changes, took over the function of Ukraine's advocate in the European Union. The coincidence of internal circumstances (political fight in Ukraine) and external (changes in the EU, change of priorities) have caused that Ukraine did not become a member of the EU, despite the verified social potential. "The eastern concept" of "Kultura" gave strong grounds for Ukraine independence recognition and support during the Orange Revolution. Giedroyc' stwin-track activities in the field of shaping political views and changing stereotypes led to very good scientific, cultural and social cooperation. The border regions cooperation is developing. Foundations and non-governmental organizations carry out common effort to promote civil society.

Keywords: ULB concept, partnership, sovereignty, instrumentalization of history

\section{Актуальность восточных концепций Ежи Гедройца}

Аннотация: Ежи Гедройц публиковал "Культуру" ежемесячно в 1947-2000 годах в Мезон Лаффит под Парижем. Постепенно «Культура» стала специфическим политическим центром таких журналистов как: Юлиуш Мирошевский, Богдан Осадчук, Леопольд Унгер. Мирошевский был создателем так называемой восточной концепции, которая предполагала добрососедские отношения суверенной Польши с независимыми государствами: Украиной, Литвой и Белоруссией, которые возникнут в результате распада СССР. Эта концепция родилась в 1950-х годах, а термин УлБ (Украина, Литва, Беларусь) был впервые использован в 1973 году. Влияние журналистов заключалось в том, чтобы убедить общественность рационализировать исторические споры и признать чаяния независимости народов, которые в прошлом составляли Содружество. После геополитических и политических преобразований в Европе, в конце двадцатого века, было признано, что восточная концепция «Культуры» имеет современное измерение и может сформировать основу политических действий. Польша, как лидер этих изменений, взяла на себя функцию адвоката Украины в Европейском Союзе. Сочетание внутренних обстоятельств (политическая борьба в Украине) и внешних (изменения в ЕС, смена приоритетов) означало, что Украина не стала членом ЕС, несмотря на подтвержденный социальный потенциал. Тем не менее, восточная концепция «Культуры» была сильной предпосылкой для признания независимости и поддержки Украины во время Оранжевой революции. Двусторонняя деятельность Гедройца в области формирования политических взглядов и изменения стереотипов позволила 
Pobrane z czasopisma Wschód Europy http://journals.umcs.pl/we

Data: 26/04/2023 14:44:20

Aktualność wschodnich koncepcji Jerzego Giedroycia

научному, культурному и социальному сотрудничеству работать очень хорошо. Сотрудничество в приграничных регионах развивается. Фонды и неправительственные организации ведут совместные инициативы для гражданского общества.

Ключевые слова: концепция УЛБ, партнерство, суверенитет и инструментализация истории

\section{Bibliografia}

Berberyusz E., Książę z Maisons-Laffitte, Gdańsk 1994.

Deklaracja w sprawie ukraińskiej, „Kultura” 1977, nr 5/356, s. 66-67.

Dlaczego nie przyjechałem do Polski. Doktorat honoris causa dla Giedroycia, "Gazeta Wyborcza” 1991, nr 262, s. 7.

Droga na Wschód. Z Jerzym Giedroyciem rozmawia M. Zieliński, „Więż” 1989, nr 10 (397), s. 42-50.

Giedroyc J., Autobiografia na cztery ręce, oprac. K. Pomian, Warszawa 1994, s. 228.

Giedroyc J., Polak zachodni, „Polityka” 1999, nr 47 (2220), s. 66.

Hofman I., Kroniki emigracyjne paryskiej „Kultury”. Rekonesans badawczy , „Annales Universitatis Mariae

Curie-Skłodowska, sectio K. Politologia", Lublin 2002, s. 87-99.

Jaka Polska na XXI wiek?, „Kultura” 1995, nr 10/577, s. 4-111.

Kosman M., Jerzy Giedroyc - człowiek instytucja, [w:] M. Kosman, Z rozważań nad kulturą polityczną w Polsce, cz. 2, Poznań 2001, s. 101-115.

Kubik M., Rozmowa z Czesławem Miłoszem, "Gazeta Uniwersytecka UŚ, dodatek kulturalny, 14.09. 2001, nr 3, s. 19.

Kubik M., Rozmowa z Jerzym Giedroyciem, „Gazeta Uniwersytecka UŚ, dodatek kulturalny, 14.09.2001, nr 3, s. 18.

Linia podziału. Z Krzysztofem Pomianem rozmawia Andrzej Garlicki, „Polityka” 1994, nr 49 (1961), s. 3. Londyńczyk, Kronika angielska, „Kultura” 1970, nr 9/276.

Łobodowski J., Przeciw upiorom przeszłości, „Kultura” 1952, nr 2/52-3/53, s. 48.

Michnik A., Jak być Polakiem na paryskim bruku, [w:] Jerzy Giedroyc. Redaktor, Polityk, Człowiek, red.

K. Pomian, Lublin 2001, s. 135-150.

Mieroszewski J., Amerykańska „Ostpolitik” i wnioski, „Kultura” 1972, nr 7/298-8/299.

Mieroszewski J., O banałach i cudach w polityce, „Kultura" 1972, nr 4/295.

Mieroszewski J., Polska "Ostpolitik”, „Kultura” 1973, nr 6/309, s. 76.

Mieroszewski J., Polska "Westpolitik”, „Kultura” 1973, nr 9/312.

Mieroszewski J., Rosyjski „kompleks polski” i obszar ULB, „Kultura” 1974, nr 9/324, s. 9.

Pomianowski J., Prawdziwy król bez ziemi, „Rzeczypospolita”, dodatek „Plus-Minus”, 2000, nr 37 (403), s. 2.

Pomianowski J., Wspomnienia o Jerzym Giedroyciu, "Gazeta Wyborcza” 16-17.09.2000, nr 218.3518, s. 17-18.

Xiążę Redaktorów. Wspominają go „Gazeta Wyborcza”, 16-17.09.2000, nr 217.3518, s. 10-12. 